\title{
Income and Expenses of Eighth District Member Banks
}

\author{
by R. ALTON GILBERT
}

\begin{abstract}
N ET INCOME of member banks in the Eighth Federal Reserve District increased 3.5 percent in 1972 to $\$ 153$ million, compared to a 7.1 percent increase in 1971. The rate of return on equity capital was 11.2 percent, down slightly from 11.4 percent in the previous year. Operating expenses increased at a faster rate than operating income in 1972, but a decline in income taxes resulted in the small rise in net income.
\end{abstract}

The profitability of banks depends upon a number of factors including existing business conditions, bank size, efficiency of operations, leverage (volume of deposits to equity capital), and the extent of competition among banks. Overall bank profitability and some determinants of profitability can be measured by using a number of operating ratios as rate of return on capital, rate of return on assets, ratio of capital to assets, rate of return on loans, and labor costs to operating income.

These ratios vary among banks of different size groups and among banks in different types of market areas. This article discusses these variations among member banks in the Eighth Federal Reserve District and points out some possible causal factors for the differences.

\section{MNCONE AND EXPENSES}

Total operating income of member banks in the Eighth Federal Reserve District increased 10 percent in 1972 , compared to a 7.6 percent increase in the previous year (Table I). Operating income of banks consists primarily of earnings on loans and investments, income from trust departments, and service charges on deposit accounts. Income from loans rose 10.6 percent, significantly higher than the 2.2 percent increase in the previous year. This change reflects primarily the growth in the volume of loans since the average rate of return on loans was 8.1 percent in both years.
Meanwhile, total operating expenses increased 12.9 percent in 1972 , as compared to an 11.3 percent increase in the previous year. Interest paid on deposits, which accounted for 42 percent of operating expense in 1972 , increased 14.2 percent. The rise in interest on deposits reflects primarily a larger volume of time and savings deposits, as the average rate paid remained unchanged at 4.8 percent.

Income before income taxes and security gains or losses declined 1.2 percent. However, income taxes declined by more than operating income, producing a 3.5 percent rise in net income. The decline in income taxes reflected in part a larger portion of operating income derived from nontaxable securities, and in part a change in tax accounting procedures. Income from nontaxable state and local government securities was 9 percent of operating income in 1972, compared to 8.5 percent in the previous year. Net income adjusted for inflation (real net income) rose by only 0.5 percent, compared to a 2.4 percent increase in $1971^{1}$

\section{OPRTATING RATIOS}

Many of the bank operating ratios supply interesting information about bank profitability. Some of these ratios for member banks in the Eighth Federal Reserve District vary according to bank size and location. These variations are shown in Table II which gives selected operating ratios by size groups and by location inside or outside metropolitan areas for the years 1970-72.

\section{Pate of Return on Equity Capinal}

The rate of return on equity capital tended to be higher for banks located outside metropolitan areas than for banks of the same size inside metropolitan

Calculated by deftating net income by the implicit price deflator for gross national product. 


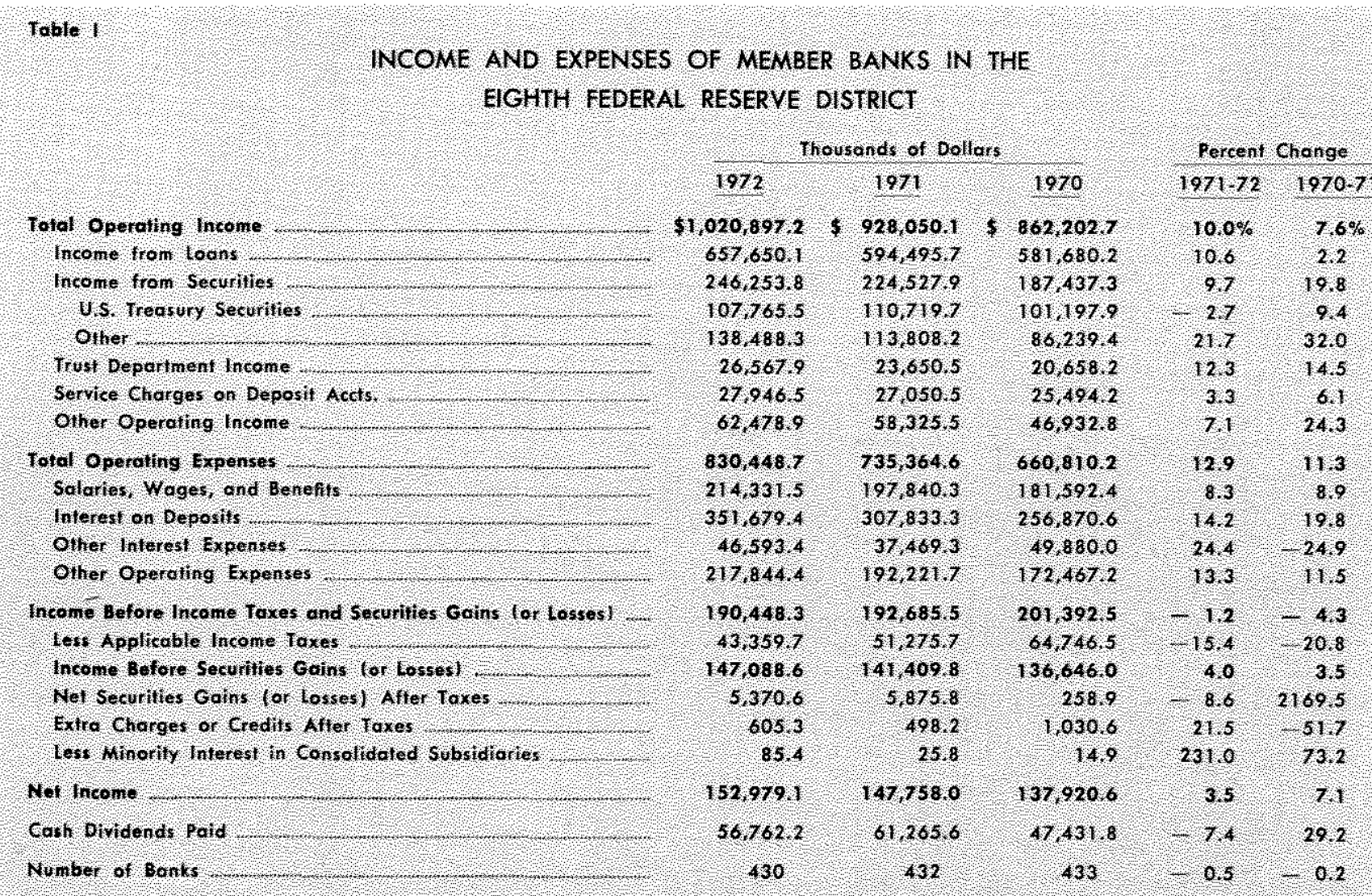

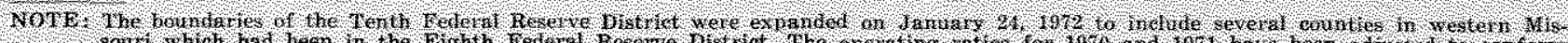

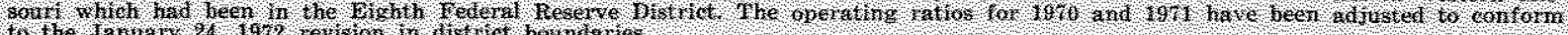

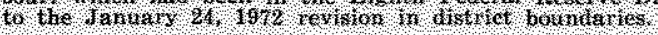

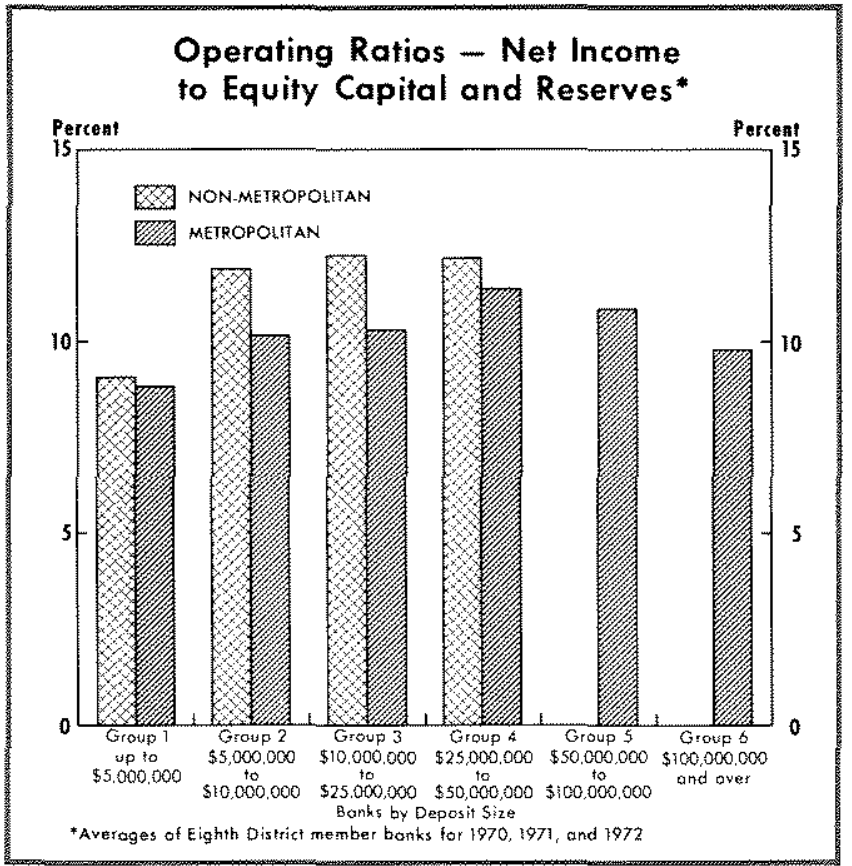

areas (see Ratio 1 in Table II). This pattern held for each of the four size groups compared in Table II; banks in these groups had deposits up to $\$ 50$ million.
The rate of return on bank capital is influenced by many factors, including the ratio of capital to total assets, efficiency of operations, and intensity of competition. Capital to total assets is not greatly different between the metropolitan and nonmetropolitan area banks. Nonmetropolitan area banks may achieve some efficiencies through lower labor costs, but these efficiencies may be partly offset by less automation. If these efficiencies are largely offset, the lower rate of return on bank capital in metropolitan areas may reflect greater competition among these banks. Bank customers in metropolitan areas generally have more banking alternatives than those in nonmetropolitan areas. They generally live and work within a short distance of a number of competing banks, thus a larger number of banks are likely to be competing for each customer's account.

Banks in the smallest size group (deposits up to $\$ 5$ million) had the lowest average rate of return on capital, and those with deposits between $\$ 10$ million and $\$ 50$ million had the highest rates of return, aver aging around 11 to 12 percent. The average rate of retum to banks with deposits greater than $\$ 100 \mathrm{mil}$ - 
SELECTED OPERATING RATIOS OF MEMBER BANKS FOR THE YEARS 1970, 1971, AND 1972 EIGHTH FEDERAL RESERVE DISTRICT* (Operating fatios in percentages)

Banks by Deposit Size

\begin{tabular}{|c|c|c|c|c|c|c|c|c|c|c|c|}
\hline \multicolumn{12}{|c|}{ Banks by Deposit Size } \\
\hline \multicolumn{2}{|c|}{$\begin{array}{c}\text { Group } 1 \\
\text { up } \\
\text { to } \\
\$ 5,000,000\end{array}$} & \multicolumn{2}{|c|}{$\begin{array}{c}\text { Group } 2 \\
\$ 5,000,000 \\
\text { to } \\
\$ 10,000,000\end{array}$} & \multicolumn{2}{|c|}{$\begin{array}{c}\text { Group } 3 \\
\$ 10,000,000 \\
\text { to } \\
\$ 25,000,000\end{array}$} & \multicolumn{2}{|c|}{$\begin{array}{c}\text { Group } 4 \\
\$ 25,000,000 \\
\text { to } \\
\$ 50,000,000\end{array}$} & \multicolumn{2}{|c|}{$\begin{array}{c}\text { Group } s \\
\$ 50,000,000 \\
\text { to } \\
\$ 100,000,000\end{array}$} & \multicolumn{2}{|c|}{$\begin{array}{c}\text { Group } 6 \\
\$ 100,000,000 \\
\text { and } \\
\text { over }\end{array}$} \\
\hline $\begin{array}{l}\text { Non } \\
\text { Metro- } \\
\text { politan }\end{array}$ & $\begin{array}{l}\text { Metro- } \\
\text { politan }\end{array}$ & $\begin{array}{l}\text { Non } \\
\text { Metro- } \\
\text { politan }\end{array}$ & $\begin{array}{l}\text { Metro } \\
\text { politan }\end{array}$ & $\begin{array}{l}\text { Non } \\
\text { Metro } \\
\text { politan }\end{array}$ & $\begin{array}{l}\text { Melro- } \\
\text { politan }\end{array}$ & $\begin{array}{l}\text { Non } \\
\text { Metro- } \\
\text { politan }\end{array}$ & $\begin{array}{l}\text { Metro- } \\
\text { politan }\end{array}$ & $\begin{array}{l}\text { Non } \\
\text { Metro- } \\
\text { politan }\end{array}$ & $\begin{array}{l}\text { Metro- } \\
\text { politan }\end{array}$ & $\begin{array}{l}\text { Non } \\
\text { Metro- } \\
\text { politan }\end{array}$ & $\begin{array}{l}\text { Metro- } \\
\text { politon }\end{array}$ \\
\hline 9.70 & 8.40 & I 2.34 & 10.81 & 12.11 & 9.14 & 12.14 & 11.08 & & 11.41 & & 9.46 \\
\hline 9.25 & 9.80 & 12.00 & 10.46 & 12.31 & 10.68 & 12.10 & 11.59 & & 10.50 & & 10.13 \\
\hline 8.25 & 8.34 & 11.36 & 9.18 & 12.33 & 11,06 & 12.26 & 11.45 & & 10.61 & & 9.66 \\
\hline 9.07 & 8.85 & 11.90 & 10.15 & 12.25 & 10.29 & 12.17 & 11.37 & & 10.84 & & 9.75 \\
\hline 1.03 & 0.79 & 1.06 & 0.88 & 1.00 & 0.80 & 1.03 & 1.06 & & 0.89 & & 0.84 \\
\hline 0.95 & 0.91 & 1.05 & 0.82 & 0.97 & 0.90 & 0.99 & 1.03 & & 0.84 & & 0.83 \\
\hline 0.79 & 0.70 & 0.96 & 0.79 & 0.94 & 0.91 & 1.03 & 0.87 & & 0.84 & & 0.75 \\
\hline 0.92 & 0.80 & 1.02 & 0.83 & 0.97 & 0.87 & 1.02 & 0.99 & & 0.88 & & 0.81 \\
\hline 7.92 & 8.24 & 7.99 & 8.46 & 8.14 & 7.70 & 8.25 & 8.08 & & 8.04 & & 8.34 \\
\hline 8.09 & 8.26 & 8.14 & 8.17 & 8.18 & 8.01 & 8.13 & 7.85 & & 7.74 & & 7,67 \\
\hline 8.18 & 8.25 & 8.20 & 8.48 & 8.13 & 8.25 & 8.04 & 7.88 & & 7.59 & & 7.62 \\
\hline 8.06 & 8.25 & 8.11 & 8.37 & 8.15 & 7,99 & 8.74 & 7.94 & & 7.79 & & 7.88 \\
\hline-0.34 & -0.62 & -0.29 & -0.29 & -0.25 & -0.28 & -0.29 & -0.15 & & -0.30 & & -0.54 \\
\hline-0.18 & -0.21 & -0.17 & -0.11 & -0.20 & -0.19 & -0.28 & -0.26 & & -0.14 & & -0.22 \\
\hline-0.17 & -0.17 & -0.13 & -0.06 & $-0,13$ & -0.17 & -0.15 & -0.11 & & -0.16 & & -0.12 \\
\hline-0.23 & -0.33 & -0.20 & -0.15 & -0.19 & -0.21 & -0.24 & -0.17 & & -0.20 & & -0.29 \\
\hline 56.77 & 55.37 & 59.47 & 80.27 & 62.66 & 62.79 & 65.51 & 62.37 & & 68.19 & & 71.12 \\
\hline 56.47 & 55.77 & 58.18 & 57.90 & 60.84 & 62.72 & 65.04 & 59.73 & & 63.61 & & 66.86 \\
\hline 55.94 & 55.48 & 59.19 & 63.44 & 61.26 & 60.09 & 62.67 & 63.84 & & 62.11 & & 67.31 \\
\hline 56.39 & 55.54 & 58.95 & 60.54 & 61.59 & 61.87 & 64.41 & 61.98 & & 64.64 & & 68.43 \\
\hline 6.85 & 8.52 & 6.74 & 10.84 & 8.52 & 10.39 & 10.61 & 13.28 & & 10.52 & & 14.53 \\
\hline 6.69 & 8.50 & 6.44 & 9.14 & 7.98 & 11.37 & 9.89 & 14.65 & & 12.15 & & 16.51 \\
\hline 6.50 & 7.35 & 6.02 & 10.02 & 7.86 & 11.37 & $\$ 1.92$ & 9.27 & & 10.28 & & 15.36 \\
\hline 6.68 & 8.12 & 6.40 & 10.00 & 8.12 & 11.04 & 10.81 & 12.40 & & 10.98 & & 15.47 \\
\hline
\end{tabular}

\section{Operating Retio}

(1) Net Income to Equity Capital Including all Reserves

1970
1971
1972
Average

(2) Net Income to Tolal Assets

1970
1971
1972
Average

(3) Interest and Fees on Loans to Loans

1970
1971
1972

Average

(4) Net Loss (-) or Recoveries on Loans to Total loans

1970
1971
1972

Average

(5) Interest and fees on Loons to Total Operating Income

1970
1971
1972

Average

(6) Income from Sources other than loans and Investments to Total Operating Income

1970
1971
1972
Average




\section{Operating Ratio}

(7) Trusł Deparfment Income to Total Operating Income

1970
1971
1972

(8) Salaries, Wages, and Officer and Employee Benefits to Total Operating Income

1970
1971
1972

Average

(9) Tofal Capilal Accounts and Reserves to Total Assets

1970
1971
1972
Average

(10) Capital Notes and Debentures to Total Capital

1970
1971
1972

Average

111) Interest on Capital Notes and Debentures to Total Operating Income

1970
1971
1972
Average

Number of Banks

1971

1972

\begin{tabular}{|c|c|c|c|c|c|c|c|c|c|c|c|}
\hline \multicolumn{2}{|c|}{$\begin{array}{c}\text { Group } 1 \\
\text { up } \\
\text { to } \\
\$ 5,000,000\end{array}$} & \multicolumn{2}{|c|}{$\begin{array}{c}\text { Group 2 } \\
\$ 5,000,000 \\
\text { to } \\
\$ 10,000,000\end{array}$} & \multicolumn{2}{|c|}{$\begin{array}{c}\text { Group } 3 \\
\$ 10,000,000 \\
\text { to } \\
\$ 25,000,000\end{array}$} & \multicolumn{2}{|c|}{$\begin{array}{c}\text { Group } 4 \\
\$ 25,000,000 \\
\text { to } \\
\$ 50,000,000\end{array}$} & \multicolumn{2}{|c|}{$\begin{array}{c}\text { Group } 5 \\
\$ 50,000,000 \\
\text { to } \\
\$ 100,000,000\end{array}$} & \multicolumn{2}{|c|}{$\begin{array}{c}\text { Group } 6 \\
\$ 100,000,000 \\
\text { and } \\
\text { over }\end{array}$} \\
\hline $\begin{array}{l}\text { Non } \\
\text { Metro- } \\
\text { politan }\end{array}$ & $\begin{array}{l}\text { Metro } \\
\text { politan }\end{array}$ & $\begin{array}{l}\text { Non } \\
\text { Metro. } \\
\text { politan }\end{array}$ & $\begin{array}{l}\text { Metro- } \\
\text { politan }\end{array}$ & $\begin{array}{l}\text { Non } \\
\text { Metro- } \\
\text { politan }\end{array}$ & $\begin{array}{l}\text { Metro- } \\
\text { politan }\end{array}$ & $\begin{array}{l}\text { Non } \\
\text { Metro- } \\
\text { palitan }\end{array}$ & $\begin{array}{l}\text { Metro- } \\
\text { politon }\end{array}$ & $\begin{array}{l}\text { Non } \\
\text { Metro } \\
\text { politan }\end{array}$ & $\begin{array}{l}\text { Metro- } \\
\text { politan }\end{array}$ & $\begin{array}{l}\text { Non } \\
\text { Metro- } \\
\text { politan }\end{array}$ & $\begin{array}{l}\text { Metro- } \\
\text { politan }\end{array}$ \\
\hline
\end{tabular}

$\begin{array}{llllllll}0.03 & 0.00 & 0.18 & 0.06 & 0.41 & 0.81 & 1.17 & 4.09 \\ 0.13 & 0.41 & 0.18 & 0.05 & 0.41 & 0.53 & 0.95 & 4.56 \\ 0.11 & 0.71 & 0.13 & 0.53 & 0.29 & 0.45 & 2.38 & 0.72 \\ 0.09 & 0.37 & 0.16 & 0.21 & 0.37 & 0.60 & 1.50 & 3.12\end{array}$

\section{$\begin{array}{llllllll}23.56 & 23.77 & 21.86 & 21.46 & 20.21 & 22.93 & 21.66 & 23.62\end{array}$}

$\begin{array}{llllllll}23.31 & 23.68 & 21.28 & 22.44 & 19.68 & 22.79 & 20.37 & 22.97\end{array}$

$\begin{array}{llllllll}23.59 & 26.75 & 20.95 & 21.00 & 19.11 & 21.96 & 19.62 & 21.01\end{array}$

$\begin{array}{llllllll}23.49 & 24.73 & 21.36 & 21.63 & 19.67 & 22.56 & 20.55 & 22.53\end{array}$

$20.55 \quad 22.53$

1.14
1.49
1.37

3.50

3.56

$\begin{array}{ll}1.37 & 3.32 \\ 1.35 & 3.46\end{array}$

22.00

22.25

22.34

22.20

$\begin{array}{rrrrrrrr}10.61 & 9.26 & 8.87 & 9.30 & 8.47 & 8.50 & 8.59 & 9.87 \\ 10.30 & 10.72 & 9.04 & 8.44 & 8.08 & 8.92 & 8.46 & 9.33 \\ 10.22 & 8.00 & 8.78 & 8.92 & 7.86 & 8.81 & 8.68 & 8.11\end{array}$

20.24
21.35

20.13

20.57

9.42

8.84

8.44

$\begin{array}{lllllllll}10.38 & 9.33 & 8.90 & 8.89 & 8.14 & 8.74 & 8.58 & 9.10\end{array}$

$$
8.53
$$

8.41

8.90

$\begin{array}{llllllll}0.15 & 0.00 & 0.34 & 1.14 & 0.76 & 0.29 & 0.00 & 2.23 \\ 0.00 & 0.00 & 0.37 & 1.36 & 0.55 & 0.20 & 1.50 & 2.21 \\ 0.00 & 0.00 & 0.13 & 0.00 & 0.97 & 1.75 & 1.44 & 2.46 \\ 0.05 & 0.00 & 0.28 & 0.83 & 0.76 & 0.75 & 0.98 & 2.30\end{array}$

5.18

4.48

$5.02-4.57$

$\begin{array}{llllllllll}0.01 & 0.00 & 0.02 & 0.10 & 0.06 & 0.02 & 0.00 & 0.17 & 0.39 & 0.36\end{array}$

$\begin{array}{llllllll}0.01 & 0.00 & 0.02 & 0.10 & 0.06 & 0.02 & 0.00 & 0.17 \\ 0.00 & 0.00 & 0.02 & 0.13 & 0.03 & 0.01 & 0.19 & 0.15 \\ 0.00 & 0.00 & 0.01 & 0.00 & 0.06 & 0.12 & 0.12 & 0.15\end{array}$

$$
0.47
$$

0.36

$0.00 \quad 0,00$

$0.02 \quad 0.08$

$0.05 \quad 0.05$

$0.10 \quad 0.16$

0.43

0.42

0.39

$\begin{array}{lrrrrrrr}83 & 8 & 114 & 14 & 129 & 27 & 30 & 17 \\ 58 & 8 & 98 & 11 & 138 & 30 & 30 & 14 \\ 48 & 4 & 82 & 15 & 148 & 28 & 38 & 15\end{array}$

*The selected operating ratios are presented for each group in which there was an average of five or more banks during the years $1970-72$. 
lion was 9.75 percent. The higher rate of return on capital among banks with $\$ 10$ million to $\$ 50$ million in deposits may reflect the higher efficiencies of banks in this category; the lower rate of return to banks with over $\$ 50$ million in deposits may reflect the influence of greater competition offsetting to some extent the economies of scale. The very large banks compete throughout the nation for the larger corporate accounts.

\section{Net Income as a Percentage of Total Assets}

Bank size and location also had an impact on net income as a percentage of total assets (see Ratio 2). Banks in nonmetropolitan areas had higher returns on total assets than similar sized banks in metropolitan areas. Moderately sized banks (deposits of $\$ 5$ million to $\$ 50$ million) had the highest returns on total assets for both metropolitan area and nonmetropolitan area banks. These returns are probably influenced by both efficiencies of scale and competition, and indicate that the pattern of rates of return on capital to banks of different sizes and location is not completely determined by variations in leverage. The higher returns on assets at medium-size banks may reflect rising returns to scale. The degree of competition in their respective markets, however, may be the chief causal factor in the higher returns to banks in nonmetropolitan areas and the lower returns at large banks which operate in the more competitive metropolitan area markets.

\section{Rate of Interest on Lorns}

One of the determinants of the profitability of banks is their rate of interest of loans. According to Ratio 3 , the average interest rate was about 8 percent during the period 1970-72. Interest rates at banks with deposits up to $\$ 10$ million were above average and rates at banks in metropolitan areas with deposits greater than $\$ 10$ million were below average. Interest rates were lowest for banks with deposits over $\$ 50$ million. There were no systematic differences between rates on loans for banks of the same size in metropolitan and nonmetropolitan areas.

These differences in interest rates on loans do not necessarily indicate that customers were charged higher interest rates for the same types of loans at small banks. Since the rate of interest on loans for each bank equals its total interest and fees as a percentage of total loans shown on the Reports of Condition, the type or size of loans made is not held constant in calculating the average rates.

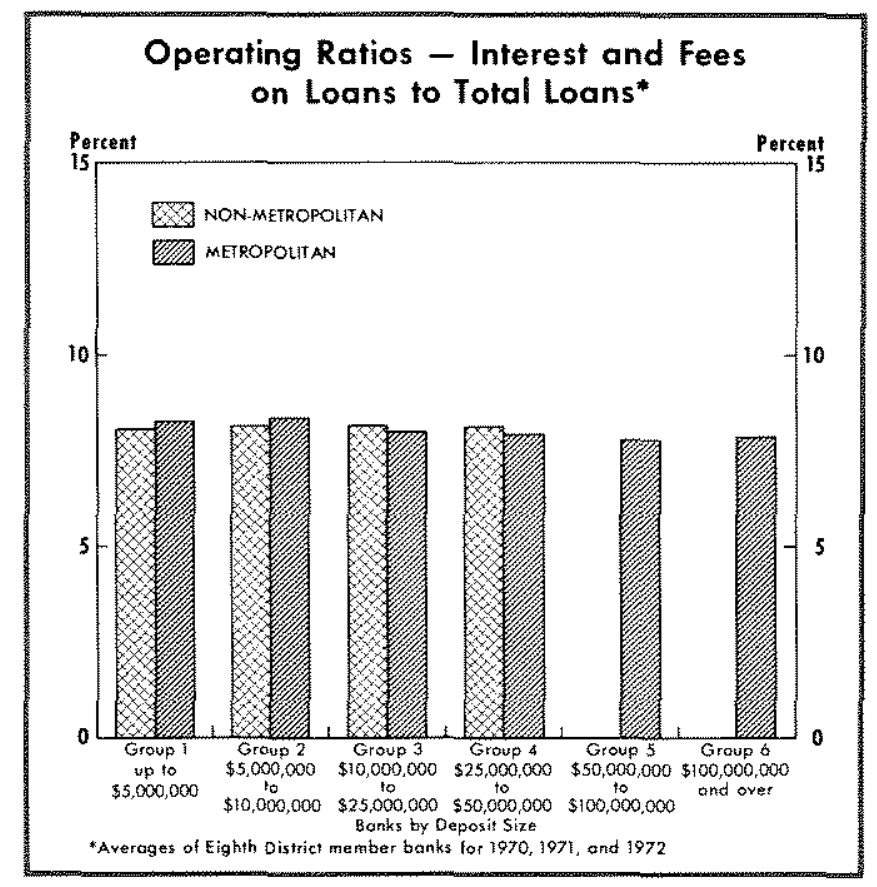

The average net loss or recovery on loans as a percentage of total loans shows no obvious pattern according to bank size or location (see Ratio 4). Therefore, the average rate of interest on loans has the same pattern with average loan losses subtracted. One consistent pattern is that loan losses tended to be greatest during 1970 , a year of recession, and lowest during 1972 , the second year of the recent recovery.

\section{Interest and Fees on Loans to Total Operating Income}

Another determinant of the profitability of banks is the proportion of operating income derived from loans

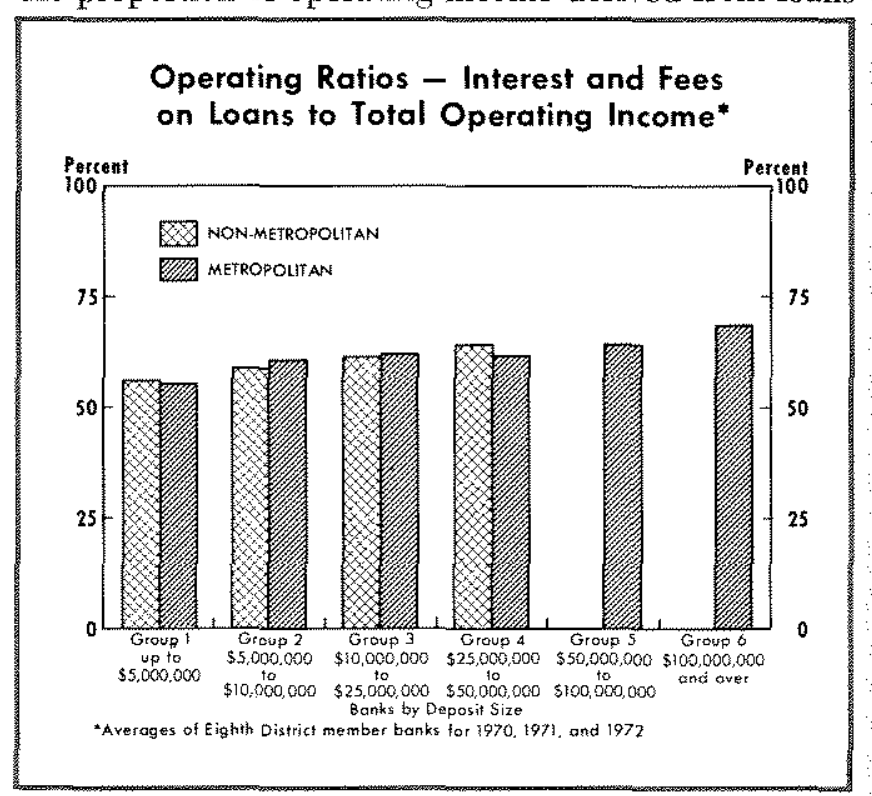




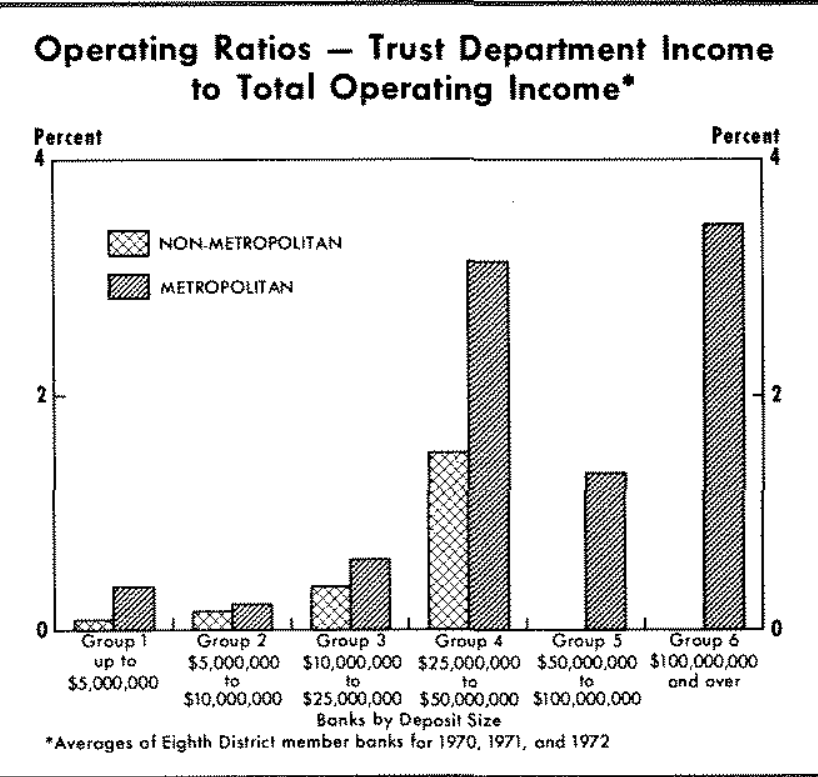

(interest rates are generally higher on loans than on securities). Ratio 5 suggests that the percentage of operating income from loans was positively related to bank size. The smallest banks (deposits up to $\$ 5$ million) received about 55-56 percent of their operating income from loans, and the largest banks (deposits of $\$ 100$ million and over) received an average of 68 percent of their operating income from loans.

\section{Percentage of Income from Sources other than Loons and Investments}

One measure of the extent to which banks offer varied services is the percentage of operating income derived from sources other than loans and investments (Ratio 6). This measure appears to be related to both bank size and location. In general, the larger banks and banks in metropolitan areas received a greater percentage of income from sources other than loans and investments.

One of the more important sources of such income is that derived from trust departments. The percentage of operating income from trust departments is positively related to bank size and is larger for banks in metropolitan areas than for nonmetropolitan area banks in the same size group (see Ratio 7). These results are consistent with the propositions that the demand for trust services at banks of equal size tends to be greater in metropolitan areas and that larger banks benefit from offering specialized trust services.

\section{Labor Costs}

Variations in the ratio of labor costs to operating income were not greatly different among banks of different sizes and locations (see Ratio 8). This ratio tended to be slightly higher for banks in metropolitan areas, possibly reflecting the influence of higher wage rates. The ratio was also higher for banks in the smallest size category (deposits up to $\$ 5$ million), possibly reflecting the lack of automation.

\section{Total Capital to Total Assets}

The profitability of banks is partially determined by their leverage, measured in Ratio 9 as the ratio of total capital to assets. The lower this ratio, other things held constant, the higher the rate of return on capital. Banks in the smallest size group had the highest and banks with deposits between $\$ 10$ million and $\$ 25$ million had the lowest average ratio of capital to assets. Since the relation between capital and assets is to some extent dictated by bank regulatory agencies, it is difficult to determine what economic forces these ratios reflect.

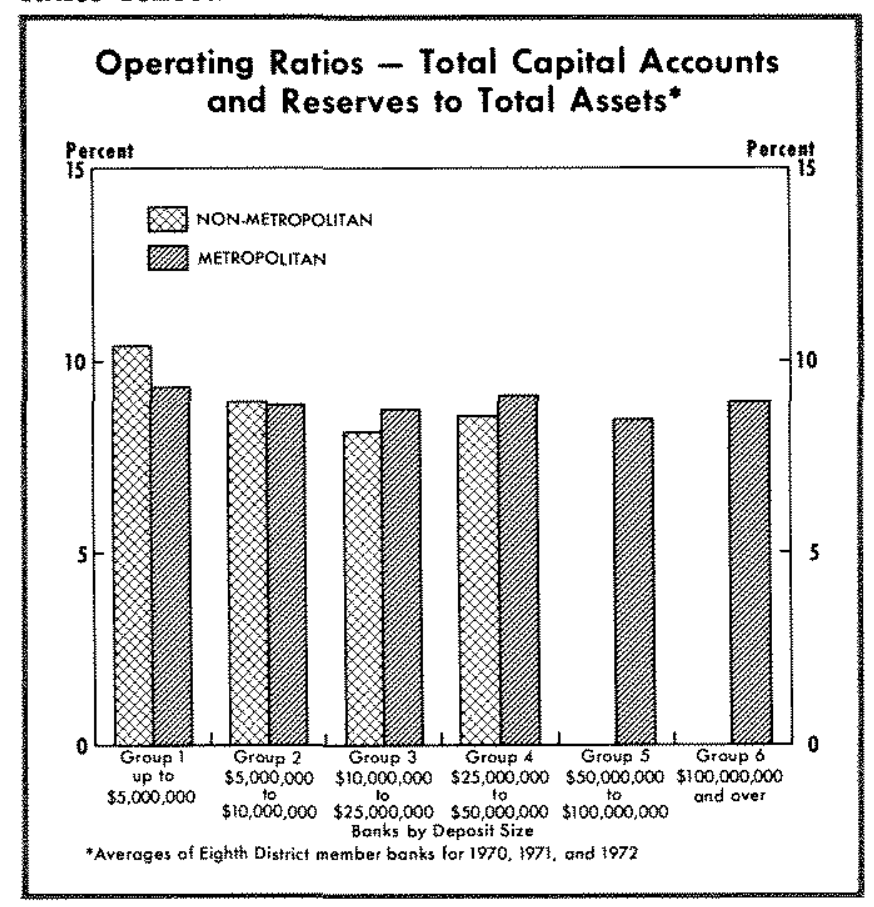

\section{Capital Notes and Debentares}

In recent years banks have been adding to their capital accounts by issuing capital notes that are subordinated to deposit liabilities. Such notes give depositors more protection and the banks more leverage for equity capital. Ratio 10 shows capital notes as a percentage of total capital accounts. There is some indication that banks in metropolitan areas have issued more capital notes than nonmetropolitan area banks. Also, larger banks have tended to issue more capital notes than smaller banks. Ratio 11 shows interest on capital notes as a percentage of total operating 
income. This ratio has much the same pattern among the banks by size groups and location as the ratio of such notes to total capital.

\section{SUMMARY}

Income before income taxes and securities gains or losses for member banks in the Eighth Federal Reserve District declined in 1972. Total operating income increased 10 percent, but total operating expenses increased faster. Interest on deposits increased at even more rapid rates, reflecting the growth of time and savings deposits. A reduction in income taxes due to a shift of bank assets into nontaxable securities and changes in tax accounting procedures accounted primarily for a 3.5 percent rise in net income.

A number of operating ratios of Eighth District member banks for 1970-72 are shown to vary according to bank size and location. Average rates of return on equity capital were higher for banks of the same size in nonmetropolitan areas than for those in metropolitan areas. Banks with deposits between $\$ 10$ million and $\$ 50$ million had higher rates of return than banks in other size categories. Banks with deposits over $\$ 50$ million had a lower average rate of return on loans than those in smaller size categories. The percentage of total operating income from loans was positively related to bank size.

The rate of return on capital is influenced by the amount of capital banks have in relation to their as. sets. The higher the ratio of capital to assets, other

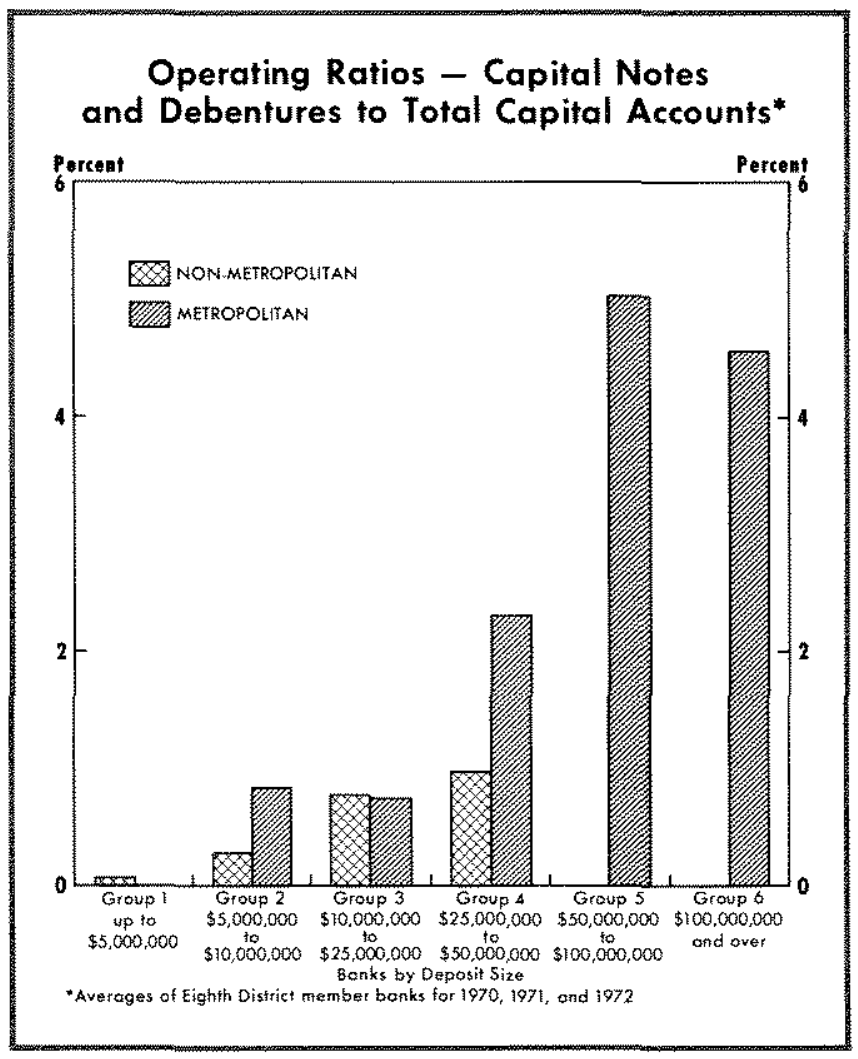

things equal, the lower the rate of return on capital. Banks of moderate size, with deposits between $\$ 10$ million and $\$ 25$ million, had the lowest average ratio of capital to total assets, which partially explains why moderately sized banks had the highest average rate of return on capital.

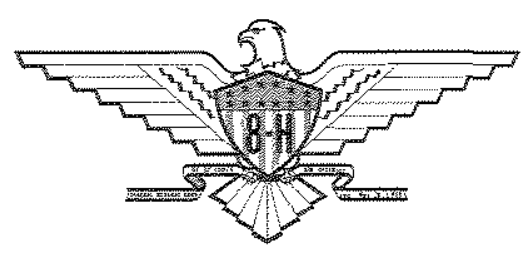

